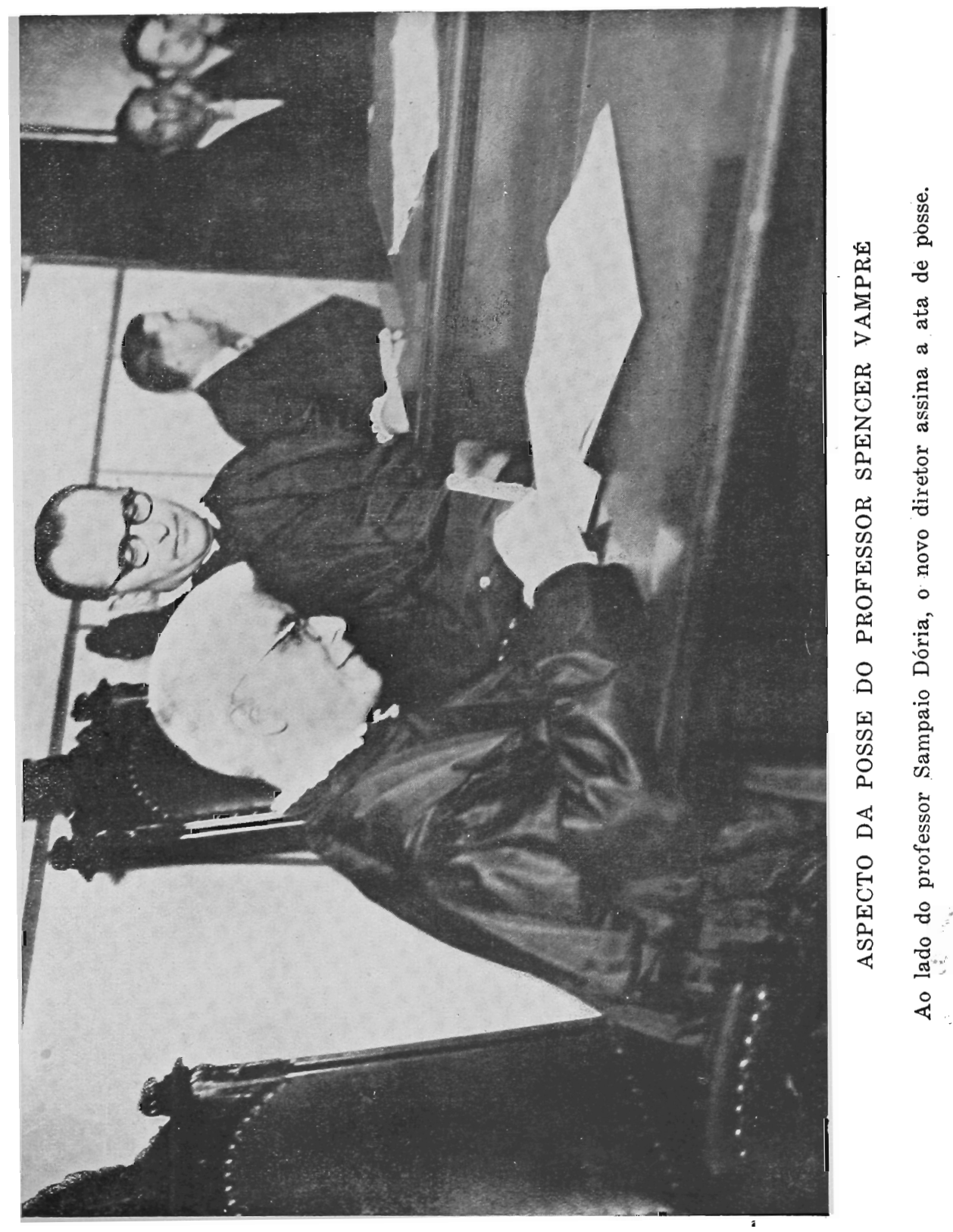




\section{O NOVO DIRETOR DA FACULDADE DE DIREITO}

\section{Professor Spencer Vampré}

Tendo o professor Francisco Morato solicitado, pelo oficio de maio do corrente ano, ao govêrno do Estado, em caracter irrevogavel, exoneração do cargo de diretor da Faculdade de Direito, foi nomeado, por decreto da interventoria federal de 9 de maio, para a alta investidura, o professor Spencer Vampré.

Noticiando esse fato, assim se expressou o "Correio Paulistano" sobre o novo diretor: "O professor Spencer Vampré é um dos mais ilustres lentes da tradicional casa de ensino do largo de São Francisco, razão pela qual o seu nome, uma vez escolhido, foi cercado de viva simpatia, merecendo os mais vivos aplausos da mocidade acadêmica. Dignificou sua carreira nos muitos e longos anos de ensino com seus largos conhecimentos jurídicos e sua inteligência fulgurante. Nascido em Rio Claro, em 24 de abril de 1888, é filho do dr. Fabricio Vampré e de d. Matilde Vampré, já falecidos. Diplomou-se em 1908, pela Faculdade de Direito de São Paulo, após um curso brilhante. Quando acadêmico, foi figura das mais salientès no memoravel Congresso de Estudantes realizado nesta capital. Fez concurso para as càtedras de Direito Civil e Direito Romano na nossa Faculdade de Direito, onde obteve o primeiro lugar, tomando posse de suas funçōes em outubro de 1917. O professor Spencer Vampré é detentor da cadeira de Introdução à Ciência do Direito, no curso de bacharelado, disciplina essa que, com reconhecida capacidade, vem ministrando ha alguns anos. Foi paraninfo da turma de bachareis do ano de 1915. E autor de vários e notaveis livros de Direito Civil e Criminal. Em 1932, ausentou-se do pais, como representante do Rotary Clube do Brasil, no Congresso Rotaryano realizado nos Estados Unidos. Foi deputado estadual e vereador à Camara Municipal de São Paulo. Sereno e justo, o professor Spencer Vampré, como diretor da Faculdade a que tanto tem servido, saberá norteá-la agora, com rumo seguro, contribuindo para a perpetuação. e glória das tradições veneraveis daquela casa secular de ensino".

Efetuou-se a cerimônia da posse do novo diretor com grande solenidade, no dia 10 de maio, na sala da congregação, achando-se 
presentes todos os professores e muitos amigos e admiradores do professor Spencer Vampré.

Aberta a sessão pelo profesor Sampáio Dória. vice-diretor em exercicio, foram designados os professores Vicente Ráo e Jorge Americano para acompanhar á sala o novo diretor. Lida a ata de posse, o professor Sampáio Doria congratulou-se com a Faculdade de Direito pela escolha do ilustre mestre.

Em nome da congregação falou o professor Alcantara Machado, saudando o professor Spencer Vampré.

Assumindo o cargo, o novo diretor principiou por agradecer as referências á sua pessoa e aludiu ás responsabilidades do posto que acabava de lhe ser conferido. Disse que contava com o valioso auxilio de todos os seus ilustres colegas para uma brilhante orientação da Faculdade de Direito e para cujo progresso, sempre e cada vez mais crescente, dava em penhor o seu coração e o melhor da sua inteligência, afim de que, dessa forma, a obra empreendida fosse mais por amor do Brasil e de São Paulo.

\section{HOMENAGEM DAS ENTIDADES ACADEMICAS AO PROFESSOR FRANCISCO MORATO}

Patrocinada pelas entidades acadêmicas Academia de Letras da Faculdade de Direito, Associação Acadêmica "Alvares de Azevedo", Campanha Pró-Monumento aos Bandeirantes, Centro Jurídico "Glovis Bevilaqua", Partido Acadêmico Conservador e Sociedade dos Acadêmicos Amigos da Itália, foi prestada, no dia 31 de maio, na sala "João Mendes Junior", homenagem ao professor Francisco Morato, com numerosa assistência.

A homenagem foi o testemunho de apreço e reconhecimento da mocidade acadêmica de São Paulo á atuação do professor Morato, como diretor da Faculdade de Direito.

\section{COMEMORAÇÃO DA INDEPENDÊNCIA ARGENTINA NA FACULDADE DE DIREITO}

Com a presença do sr. Consul Argentino, da mocidade acedêmica e mais pessoas gradas, realizou-se, a 25 de maio, na sala "João Mendes Junior", a comemoração da data da independência da República Argentina, solenidade presidida pelo professor Spencer Vampré, di- 